\title{
BASEL III IMPACT ON BANKING SECTOR AND SMEs FINANCING
}

\author{
Florin Mihai Magda \\ "Babes - Bolyai” University Cluj - Napoca \\ florin.magda28@yahoo.com
}

\begin{abstract}
Financial crisis devastating consequences and effects started in 2008, lead to several reactions coming from the most important international organizations and entities. This article aims to present in a logic manner, synthetic, and easily understand why these prudential reactions occurred and implemented on international level, under a new Basel III framework. Moreover, this article shall encompass also regulation environment for its implementation on the European level, known as CRD IV. This article is actual and important by identifying and underlines main measures applicable in present, their implementation schedule, as well as possible effects especially in SMEs financing. Although their effects are not yet entirely known, creates heated debates and discussions, as consequences may be major for banks and financial entities, as well as for each actor who is playing on economic environment where financing is need. I consider that all my personal conclusions and opinions on this article are important for readers, clarify and bringing into the light, simply and friendly the issues of banking environment and impact of financing under the new Basel III framework, and also presenting few measures in avoiding negative possible effects.
\end{abstract}

\section{Keywords}

Basel III; CRD IV; crisis; reform rules; systemic risk; SMEs financing

\section{JEL Classification}

G21; G28; G29; G32; E44

\section{Introduction}

Considering it is very important to know which are main regulations under the new Basel III framework on the international level, but merely which borderlines on the European level are, making it possible, by this article we are bringing updated knowledge for this field, built synthetic in one material.

Unlike other previous writings belonging to foreign authors, aiming just several chapters in this large area of interest, or generally treating parts, this article may be considered complex, as it unite all important aspects dealing with new Basel III framework and regulation package CRD IV, without neglecting to treat their application in Romania.

Our desire was to be a logical structure, dealing with a chronological chain of events, presented concisely in order to permit and clarify to readers about reasons leading financial crisis occur in the year of 2008, how great international entities reacted, what is birth of Basel III framework, and why it is important to apply all over the world, and perspectives involved.

Moreover, in this article, alongside the descriptive connotations which present in a personal manner main causes generating one of the greatest global crisis, or identify national regulation permitting implementation new Basel III framework, offer to the reader a possibility to face the complex issues of limitations and future effects to produce in respect of implementation schedule of new regulations, and generate even 
questions, reflections, and possible answers regarding next capability of banking to finance of SMEs. It were SMEs that have brought in discussion, as economic grow and level of living depend on their fate, their future developing capacity, obviously incurring a capital accumulation, leading national and European economy draining.

\section{Basel III background and overview}

According to Bank for International Settlements (2010), Basel Committee on Banking Supervision based on participation of Central Bank Governors' Group and Supervision Heads (GHOS) have agreed upon general framework of the Basel III, in September of 2009, when settled to enhance the three pillars of the Basel II framework. Basel Committee has appointed Cross-border Bank Resolution Group to present particular proposals even since March of 2010. These consultative documents have compound the basis of the Commission answer to financial crisis and are part of global initiatives intended for strengthening financial reform system, as approved by G20 leaders. Subsequently, Supervising Departments heads have agreed upon keydesign elements of reform package of July 2010, and had several meetings for measures calibration and enforcement. Basel III birth can be graphically presented in a very suggestive way by Figure1.

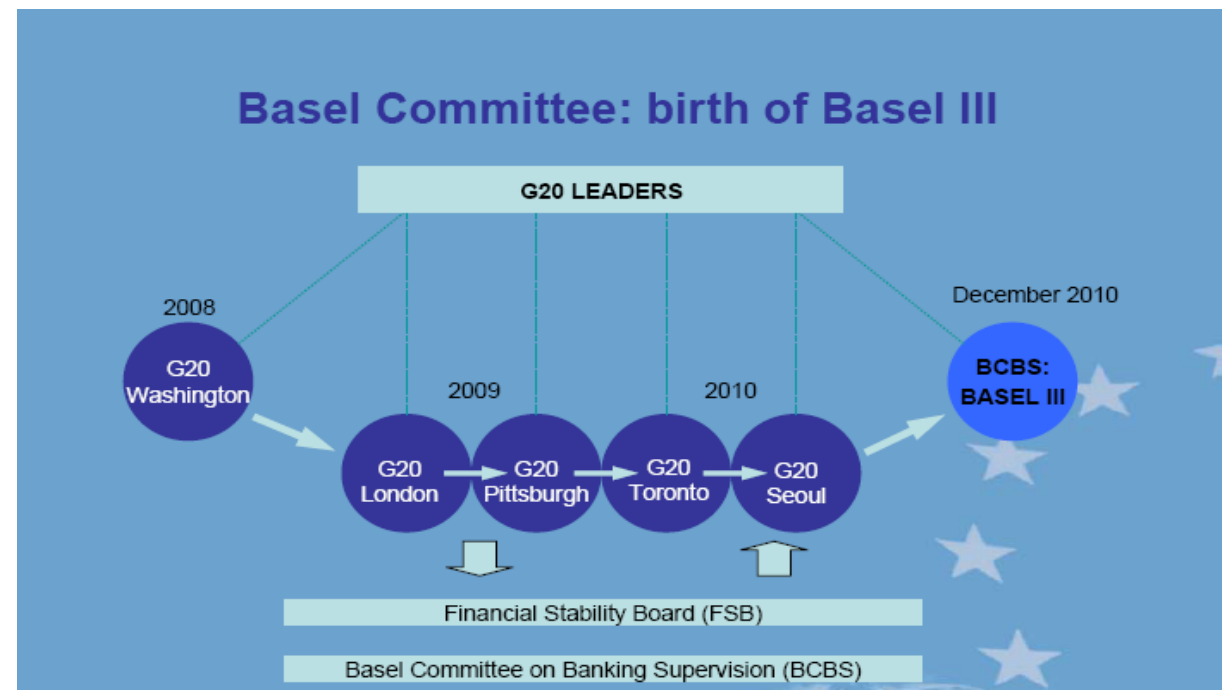

Figure 1 Basel Committee: Birth of Basel III

Source: Iordan-Constantinescu, N. (2012), CRD IV and implementation on European level of requirements of BASEL III, "Romania Where to? Challenges of the new framework Basel III” Conference Presentation, organized by National Bank of Romania

Occurring causes for crisis of 2008, and Basel III framework, as reaction to all these were several, but most important of them are as follows:

- imbalances occurred globally on macro and microeconomic level;

- insufficient ruled and supervised banking policy and financial framework (in USA, but also in other countries);

- subprime credits crisis, and speculative balloon initiated under earning desire, based on doubtful assets;

- great risks assuming coming from higher profits desire, on financial entities and banks, under conditions of highly indebtedness level of borrowers and underestimated risk; 
- financial innovation without precedent, based on non-liquid assets (mortgages) transformed in liquid assets and moving away from traditional banking;

- lower management of risk, exercised even from supervising authorities side.

As stated by Walter (2011), General Secretary of Basel Committee on Banking Supervision, main reasons for introducing Basel III framework are:

- devastating consequences of banking crisis:

There is a large range of evidence proving that each major crisis had a banking crisis as epicenter. Specialists showed that a banking crisis effects are devastating by reducing economic production even to $60 \%$ from gross domestic product existing before the crisis.

- banking crisis frequency:

Unfortunately, a banking crisis costs are severely high, as well as their frequency. Starting with 1985, there were more than 30 banking crisis in member states of Basel Committee, corresponding to a probability of $5 \%$ of facing a banking crisis in one member state in one year.

- Basel III framework benefits exceed the costs of implementing:

As a strong and resilient banking system is the cornerstone for sustainable economic growth, having long-term beneficial effects.

Unlike of Basel II (2004), Basel III (2010) has no major changing in previous framework approaching, but mostly complete mutually, capital ratio numerator simplify and consolidate, and macro prudential components were introduced dealing with regulating framework.

In a synthesized manner, the basic structure of Basel III remains unchanged with three mutually reinforcing pillars (Rajesh, 2012):

- Pillar 1: Minimum Regulatory Capital Requirements based on Risk Weighted Assets (RWAs) - maintaining capital calculated through credit, market and operational risk areas.

- Pillar 2: Supervisory Review Process - regulating tools and frameworks for dealing with peripheral risks that bank face.

- Pillar 3: Market Discipline - Increasing the disclosures that banks must provide to increase the transparency of banks.

Mainly, the objective of Basel III framework is to improve the banking sector ability to harm economy by an excessive risk.

\section{Basel III regulations, rules and directions}

As stated by Cardone-Riportella (2011) main general framework provided of Basel III is presented as follows:

- Firstly, the quantitative and qualitative level of capital was raised substantially, with emphasis on "common equity". Capital needs must be the highest quality for better absorbing shocks by losses incurred from everywhere;

- Secondly, Basel III is introducing a simple leverage ratio, which shall act as a barrier for measure on risk basis. This measure appears to be crucial for entire framework strengthening, assuring a common-sense control of proposed results, simple, easy to comprehend, in this general reform of risks control;

- The third reform of Basel III, is based on using capital reserves. Conservation reserve provide a strong impulse to banks, for their capital 
strengthening in favorable times, and in time, this reserve might help banks as a buffer against threats due to a rapid increase of credits amount ${ }^{1}$;

- Lastly, principles of liquidity risk management and global standards for liquidity shall help banks in efficiently deal with this risk, by maintaining a proper liquidity reserves.

Actually, the most important reforms of Basel Committee on Banking Supervision Basel III (2010) provide:

I) Firstly, base capital quality, coherence, and transparency shall be raised according to Table 1.

Table 1 Calibration of the Capital Framework

Capital requirements and buffers (all numbers in percent)

\begin{tabular}{|l|c|c|c|}
\hline \multicolumn{1}{|c|}{ CAPITAL (\%) } & $\begin{array}{c}\text { COMMON EQUITY } \\
\text { TIER 1 }\end{array}$ & $\begin{array}{c}\text { TIER 1 } \\
\text { CAPITAL }\end{array}$ & $\begin{array}{c}\text { TOTAL } \\
\text { CAPITAL }\end{array}$ \\
\hline Minimum & 4.5 & 6 & 8 \\
\hline Conservation Buffer & 2.5 & \multicolumn{2}{|l}{} \\
\hline $\begin{array}{l}\text { Minimum + } \\
\text { Conservation Buffer }\end{array}$ & 7.0 & 8.5 & 10.5 \\
\hline $\begin{array}{l}\text { Countercyclical } \\
\text { buffer range }\end{array}$ & $0-2.5$ & \multicolumn{2}{|l}{} \\
\hline
\end{tabular}

Source: Basel Committee on Banking Supervision - Basel III (December 2010, review June 2011), A global regulatory framework for more resilient banks and banking systems, www.bis.org

Information of table above shows that:

- Tier 1 (level 1 of capital): is the predominant capital form of Tier 1 and must include common shares and retained earnings;

- $\quad$ Tier 2: capital instruments will be harmonized;

- Tier 3 capital will be removed.

II) Secondly, covering degree of capital risk will be strengthened by:

- $\quad$ promoting of integrated management of market, and also counterparty credit risk;

- adding of CVA (credit valuation adjustment) as assessment adjusting of credit, for lowering the risk from counterparty credit downgrade;

- $\quad$ strengthening capital requirements for counterparty credits exposure coming from banks derivative instruments, REPO, and securities financing transactions;

- $\quad$ capital reserves raising for a back-up of these exposures;

- providing incentives for a better strengthen and manage the risk of counterparty credits exposures;

- $\quad$ improving standard management of risks on counterparty credits including by showing the wrong risks management.

III) Thirdly, Committee will introduce a leverage ratio as a supplementary measure for Basel II framework, which designated to attract additional guarantees against risk of model, and risk of assess error by completing the measures based on risk with a simple measure, based on gross exposures.

IV) Fourthly, Commission will introduce a pack of measures for encourages capital reserves accumulation in good times, used in stress periods for "Reducing procyclicality and promoting countercyclical buffers”:

\footnotetext{
${ }^{1}$ A capital preservation buffer of $2.5 \%$, composed by Tier 1 common shares, provided as a minimum share condition. Implementation stages of this preservation buffer shall start with 1 January 2016 and shall be fully enforced from 1 January 2019.
} 
a) Achieving macro prudential objective largely, for protection of banking sector to periods of credit rising in excess done by:

- using information projected in large periods, for assessing probability of default (PD);

- Loss Given Default (LGD) recommended in Basel II framework, becomes now mandatory;

- improving of risk functions, to transform estimates of losses in regulation regarding capital needs;

- $\quad$ stress tests organized by banks themselves.

b) Promoting of stronger practice of provisioning by making changes in accounting standards, especially regarding the approach of expected losses (EL) (usually, the value $\mathrm{EL}:=\mathrm{LGD} * \mathrm{PD} * \mathrm{EAD}$ where $\mathrm{LGD}$ means lost given default, $\mathrm{PD}$ means probability of default, EAD means exposure at default)

V) Fifthly, the Committee introduces a global standard of minimum liquidity for active international banks, providing that liquidity ratio to be covered for 30 days and to be sustained by a structural liquidity ratio for a longer term, named Net Stable Funding Ratio. In January of 2012, Committee, by a declaration permit banks to pass below their needed liquidity level as settled by Liquidity Covering Ratio, during stress periods.

After year of 2010, by reforms of Basel III framework it was tried, by the moment of debates, to achieve several percentage ratios: $7 \%$ to $9.5 \%$ (4.5\% plus $2.5 \%$ (as conservation buffer) plus 0 to $2.5 \%$ (as seasonal buffer)) for own capitals belonging to common shareholders (common equity) and of $8.5 \%$ to $11 \%$ for Tier 1 and $10.5 \%$ to $13 \%$ for total capital. These regulations and stages intended for implementation is presented in Figure 2.

(shading indicates transition periods - all dates are as of 1 January)

\begin{tabular}{|c|c|c|c|c|c|c|c|c|c|}
\hline & 2011 & 2012 & 2013 & 2014 & 2015 & 2016 & 2017 & 2018 & $\begin{array}{c}\text { As of } \\
1 \text { January } \\
2019\end{array}$ \\
\hline Leverage Ratio & \multicolumn{2}{|c|}{ Supervisory montioring } & \multicolumn{4}{|c|}{$\begin{array}{l}\text { Paralel nn } \\
\text { 1 Jan } 2013-1 \text { Jan } 2017 \\
\text { Disclosure statts } 1 \text { Jan } 2015\end{array}$} & & $\begin{array}{l}\text { Mgration to } \\
\text { Pillar } 1\end{array}$ & \\
\hline Minimum Common Equity Capital Ratio & & & $3.5 \%$ & $4.0 \%$ & $4.5 \%$ & $4.5 \%$ & $4.5 \%$ & $4.5 \%$ & $4.5 \%$ \\
\hline Capital Conservation Buffer & & & & & & $0.625 \%$ & $1.25 \%$ & $1.875 \%$ & $2.50 \%$ \\
\hline $\begin{array}{l}\text { Minimum common equity plus capital } \\
\text { conservation buffer }\end{array}$ & & & $3.5 \%$ & $4.0 \%$ & $4.5 \%$ & $5.125 \%$ & $5.75 \%$ & $6.375 \%$ & $7.0 \%$ \\
\hline $\begin{array}{l}\text { Phase-in of deductions from CET } 1 \\
\text { (including amounts exceeding the limit for } \\
\text { DTAs, MSRs and financials ) }\end{array}$ & & & & $20 \%$ & $40 \%$ & $60 \%$ & $80 \%$ & $100 \%$ & $100 \%$ \\
\hline Minimum Tier 1 Capital & & & $4.5 \%$ & $5.5 \%$ & $8.0 \%$ & $6.0 \%$ & $6.0 \%$ & $6.0 \%$ & $6.0 \%$ \\
\hline Minimum Total Capital & & & $8.0 \%$ & $8.0 \%$ & $8.0 \%$ & $8.0 \%$ & $8.0 \%$ & $8.0 \%$ & $8.0 \%$ \\
\hline $\begin{array}{l}\text { Minimum Total Capital plus conservation } \\
\text { buffer }\end{array}$ & & & $8.0 \%$ & $8.0 \%$ & $8.0 \%$ & $8.625 \%$ & $9.25 \%$ & $9.875 \%$ & $10.5 \%$ \\
\hline $\begin{array}{l}\text { Capital instruments that no longer qualify } \\
\text { as non-core Tier } 1 \text { capital or Tier } 2 \text { capital }\end{array}$ & & & \multicolumn{7}{|c|}{ Phased out over 10 year hotzon begiming 2013} \\
\hline Liquidity coverage ratio & $\begin{array}{c}\text { Ooservation } \\
\text { period } \\
\text { begins }\end{array}$ & & & & $\begin{array}{l}\text { Introduce } \\
\text { minimum } \\
\text { standard }\end{array}$ & & & & \\
\hline Net stable funding ratio & $\begin{array}{l}\text { Observation } \\
\text { period } \\
\text { begins }\end{array}$ & & & & & & & $\begin{array}{l}\text { Introduce } \\
\text { minimum } \\
\text { standaro }\end{array}$ & \\
\hline
\end{tabular}

Figure 2 Basel III regulations and implementation stages

Source: Basel Committee on Banking Supervision - Basel III (December 2010, review June 2011), A global regulatory framework for more resilient banks and banking systems, www.bis.org

Subsequently changes occurred on Basel III framework, by requesting to banks a capital adequacy ratio of at least 7\% until the year of 2019, while at European level a decision for achieving a threshold of 9\% until the end of June of 2012. 


\section{Basel III implementation in Europe by CRD IV}

The goal of CRD IV (Capital Requirements Directive) is to minimize negative consequences of companies in bankruptcy by assuring that companies possess sufficient financial resources for covering the risk associated with their business. CRD IV is the fourth amending of this regulation. Each amendment appears to strengthen the prudential framework for individual entities and respond financial stability concerns, which appeared during banking crisis.

CRD IV is composed by two regulating instruments:

- $\quad$ Capital Requirements Directive (CRD);

- $\quad$ Capital Requirements Regulation (CRR).

As stated by Romanian Financial Supervising Authority (ASF):

- regulation package CRD/CRR IV (composed by European Directive no. 2013/36/EU which needs implementation Member States legislations and respectively Regulation EU no. 575/2013 with direct enforcement in European Union Member States legislation) do represent implementation on European Community level of the Basel III framework of Basel Committee for Banking Supervision, a framework settling new capital requirements for financial entities, as response to crisis cases last years have occurred;

- adopting process of regulation package CRD/CRR IV has terminated during 2013, on June 27, 2013 by publishing in the Official Journal of European Communities of Directive no. 2013/36/EU regarding access to activity of credit entities and prudential surveillance of credit entities, and investment companies, as amending of Directive 2002/87/EC and abrogation of Directives 2006/48/EC and 2006/49/EC and Regulation EU no. 575/2013, all these being enforceable starting with the date of January 1, 2014;

- regulation package CRD/CRR IV represents the legal framework ruling prudential activity, surveillance framework, and prudential requirements enforceable to credit entities and investment entities from Member States of European Union.

According to CRD/CRR IV, for assure that investment entities have an internal capital proportional to assumed risks, mostly appropriate as distribution, quality, and quantity, several cooperative governing providing are imposed to be enforced for prevent assuming excessive risks, and to be monitor by supervising authorities. Moreover, similar requirements have been introduced for credit entities and investments companies, providing the obligation to possess, among the own funds, of a damper countercyclical capital for guarantee that this is under accumulation in times of economic raising, a sufficient capital base for losses absorbing during crisis periods.

Regulation basis for the package CRD/CRR IV on domestic and European level is presented below in Table 2 .

Table 2 Domestic and European regulation framework afferent CRD IV

\begin{tabular}{|c|c|c|}
\hline REGULATION & ISSUER & SUBJECT OF REGULATION \\
\hline \multicolumn{3}{|c|}{ UE Legislation } \\
\hline $\begin{array}{l}\text { Directive 2013/36/UE } \\
\text { OBS. Amends Directive } \\
\text { 2002/87/EC and revoke } \\
\begin{array}{l}\text { Directives 2006/48/EC and } \\
\text { 2006/49/EC }\end{array}\end{array}$ & $\begin{array}{l}\text { European Parliament } \\
\text { and the Council on } 26 \\
\text { June } 2013\end{array}$ & $\begin{array}{l}\text { Access to credit entities activity and } \\
\text { prudential surveillance of credit entities } \\
\text { and investment companies }\end{array}$ \\
\hline Regulation no. 575/2013 & $\begin{array}{l}\text { European Parliament } \\
\text { and the Council on } 26 \\
\text { June } 2013\end{array}$ & $\begin{array}{l}\text { Prudential requirements for credit } \\
\text { entities and investment companies } \\
\text { modifying of Regulation (EU) no. } \\
648 / 2012 \text {. }\end{array}$ \\
\hline
\end{tabular}




\begin{tabular}{|c|c|c|}
\hline $\begin{array}{l}\text { Regulation regarding } \\
\text { standards } 12.052013 \text { (EU) }\end{array}$ & $\begin{array}{l}\text { European Parliament } \\
\text { and European } \\
\text { Commission }\end{array}$ & $\begin{array}{l}\text { Technical standards for enforcement } \\
\text { regarding reports in surveillance of } \\
\text { entities according to Regulation (EU) } \\
\text { no. 575/2013 of European Parliament } \\
\text { and Council }\end{array}$ \\
\hline \multicolumn{3}{|c|}{ National regulation (Romania) } \\
\hline $\begin{array}{l}\text { OUG no. 99/2006 } \\
\text { OBS. Published in Official } \\
\text { Journal, Part I, no. } \\
\text { 1027/27.12.2006 }\end{array}$ & Govern of Romania & Credit entities and capital adequacy \\
\hline $\begin{array}{l}\text { Law no. } 227 / 2007 \\
\text { OBS. For enforcement of OUG } \\
\text { no. } 99 / 2006\end{array}$ & Romanian Parliament & Credit entities and capital adequacy \\
\hline $\begin{array}{l}\text { OUG no. } 113 / 2013 \\
\text { OBS. amending and completing } \\
\text { of OUG no. } 99 / 2006\end{array}$ & Govern of Romania & Credit entities and capital adequacy \\
\hline $\begin{array}{l}\text { Regulation ASF no. 3/2014 } \\
\text { OBS. applying of OUG 99/2006 } \\
\text { and Regulation EU 575/2013 }\end{array}$ & ASF Council & Credit entities and capital adequacy \\
\hline $\begin{array}{l}\text { Decision no.44/ } 20.02 .2014 \\
\text { OBS. for applying of providing } \\
\text { of article } 126 \text { of Emergency } \\
\text { Govern Ordinance no. 99/2006 }\end{array}$ & Govern of Romania & Credit entities and capital adequacy \\
\hline
\end{tabular}

\section{BASEL III impact on SME's financing}

Constraints on borrowing were defined by OECD (2006), as occurring when SMEs cannot obtain funds from banks, or any other funding providers, even though they have capacity to use these funds in a productive way. In a case when economic viable projects might be narrowed even abandoned for financing difficulties, all these constraints have a potential of severe negative consequences in innovation and development.

The great difficulty in accessing of credits SMEs facing with, in comparison with large companies consists in actual differences in their risk profile, as well as in asymmetric of information present between SMEs and a credit entity (OECD, 2006). From SMEs side it might be difficult to convince banks about quality of business plans, especially for new established companies facing with a great effort to build a reputation able to determine a low risk, and this also due to crisis of 2008. It was really encountered a repulsion of many SMEs regarding the issue of credit (risky economic climate, high costs and warranties). From the bank side, costs involved in financial valuation and SMEs monitoring is acting like a discouraging factor in funding this branch. For great banks, often prefer credit transactions having as basis companies financial status as information source. Moreover, in most cases SMEs possess few warranties than needed for comfort and safeguard of potential creditors (BCE, 2007). Personal sources of funding from the owner of SMEs at its start-up, personal assets have proven to be important sources financing obtaining after year of 2008. To all these, warranty system developed in some countries, like FNGC IMM (National Credit Guarantee Fund for SMEs) in Romania, SFLG in UK (UK Small Firms Loan Guarantee Scheme) JASMEC CGS (Credit Guarantee System for Japan Small and Medium Enterprise Corporation) in Japan, may be added.

Among these issues, during transition to new reforms of Basel III regarding banking capitalization requirements, is possible to us to observe an appetite lowering of commercial banks, or a quite suspicion in SMEs funding, under condition of considering small and medium-sized enterprises as maximum risk. Nevertheless, in Romania, by banking system transition to accounting IFRS system, large amounts of 
money have released from provisioning, and in plus there was Vienna 2.0 initiative by which great financial groups (of Austrian origin) have agreed upon continuing to fund Romanian economy, including after the crisis occurring in 2008. From the globalization point of view, it is predictable that banking sector to restrict continuously as economic and financial environment will become more unfriendly to SMEs, and small banks can't afford to loan SMEs under the new regulations.

\section{Conclusions and Perspectives}

Governors' Council, appreciate that economic expectations for euro zone encounter high risks in a way of decrease, especially taking in account existing tensions on several financial markets from euro zone, and to potential spillover effects on the real economy, the euro zone is still lying within.

According to my opinion, Basel III framework regulation implementing in our country must tuned with finding the best leverage economically and legislative for stimulate lending especially to SMEs, taking in regard their major role they play in economy, and coming after a severe crisis period when capitals almost perished, or vanished at all. This is why I consider in coming back of SMEs lending as done mainly by: financing costs lowering (by decrease of ROBOR and of intervention interest BNR is practicing on, decreasing of Romania CDS according to achieved economy growth, including a decrease of interest margins the main banks are practicing in Romania) alongside the liquidity raising on the market (by lowering of mandatory minimum provisions on lei and currencies imposed to commercial banks), raising the rate in European funds absorbing, the success of govern financing programs, but mostly the new ones achievement (as the fact minimis support is almost unfunctional in present), the offer of special warranty systems for SMEs activating in agriculture sector.

\section{References}

ASF Council, Regulation ASF no. 3/2014 regarding issues in enforcement of OUG 99/2006 and Regulation EU 575/2013.

Basel Committee on Banking Supervision (2004), Basel II: Revised international capital framework available at www.bis.org.

Basel Committee on Banking Supervision (December 2010, review June 2011), Basel III: A global regulatory framework for more resilient banks and banking systems, www.bis.org.

Basel Committee on Banking Supervision (2010), International regulatory framework for banks (Basel III), http://www.bis.org/bcbs/basel3.htm.

Cardone-Riportella, C. et al, (2011), What do Basel Capital Accords mean for SMEs?, Working Paper, 10, Universidad Carlos III de Madrid.

European Parliament and Council (2013), Directive 2013/36/EU, available at http://eurlex.europa.eu/LexUriServ/LexUriServ.do?uri=OJ:L:2013:176:0338:0 436:RO:PDF.

European Parliament and Council (2013), Regulation no. 575/2013, available at http://eurlex.europa.eu/LexUriServ/LexUriServ.do?uri=OJ:L:2013:176:0001:0 337:RO:PDF.

European Parliament and Council (2013), Regulation regarding standards (EU), available at http://www.asfromania.ro/files/international/anunturi/Regulament \%20aplicare\%20standarde_12.05.pdf.

Govern of Romania (2006), OUG no. 99/2006, published in Official Journal, Part I, no. $1027 / 27.12 .2006$. 
Govern of Romania (2013), OUG no. 113/2013 regarding several budget measures for completion of Govern Emergency Ordinance no. 99/2006, published in Official Journal, Part I, no. 830/ 23.12.2013.

Govern of Romania (2014), Decision no.44/20.02.2014, available at http://www.asfromania.ro/ files/capital/decizii/2014/DECIZIA\%20nr.\%204420.02.2014.pdf

Government of United Kingdom (1981), (SFLG) loan support scheme for small business.

Iordan-Constantinescu, N. (2012), CRD IV and implementation on European level of requirements of BASEL III, "Romania Where to? Challenges of the new framework Basel III” Conference Presentation, organized by National Bank of Romania.

Natani, M., Riding, A. (2005), Credit Guarantee Schemes: A Tool to Promote SME Growth and Innovation in the MENA Region REPORT AND GUIDELINES 2011, MENA-OECD Investment Programme Working Paper, available at http://www.oecd.org/mena/investment/47245991.pdf.

Rajesh, G. (2012), Basel III Accord - Basel 3 Norms, available at http://www.allbankingsolutions. com/Banking-Tutor/Basel-iii-Accord-Basel-3Norms.shtml.

Romanian Parliament (2007), Law no. 227/2007, available at http://www.asfromania.ro/files/ capital/legi/Legea-227-2007.pdf.

Ştefan, C. (2013), Noul Cadru de reglementare a sistemului bancar la nivelul UE, Colocviul "Spre o nouă arhitectură de supraveghere a piețelor financiare în Uniunea Europeană", available at http://www.bnr.ro/Document Information.aspx?id Document=15313\&directLink=1.

Walter, S. (2011), Basel III: Stronger Banks and a More Resilient Financial System, Conference on Basel III, Financial Stability Institute, Basel. 